\title{
Responding to physical and psychological health impacts of disasters: case study of the Iranian disaster rehabilitation plan
}

\author{
A. Ardalan, ${ }^{1,2,3}$ S. Sohrabizadeh, ${ }^{4}$ M.F. Latifi, ${ }^{5}$ M.H. Rajaei, ${ }^{2}$ A. Asadi, ${ }^{6}$ S. Mirbeigi, ${ }^{7}$ N. Rouhi ${ }^{8}$ and H. Yousefi ${ }^{2}$
}

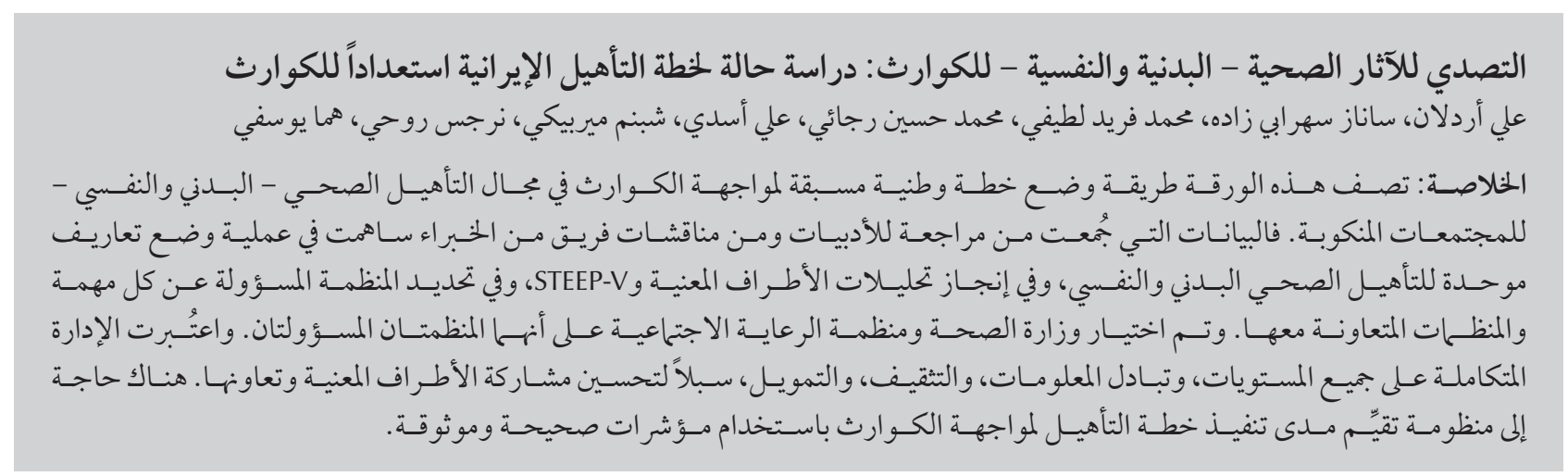

ABSTRACT This paper describes the process of developing a national pre-disaster plan for physical health and psychological rehabilitation of disaster-stricken communities. Data gathered from a literature review and expert panel discussions informed the process of drawing up unified definitions of physical and psychological health rehabilitation, carrying out stakeholder and STEEP-V analyses, and assigning the responsible organization and the collaborative organizations for each task. The Ministry of Health and the Welfare Organization were selected as the two responsible organizations. Integrated management at all levels, and sharing information, education and funding, were identified as ways to improve stakeholders' participation and collaboration. A system is needed for evaluating the implementation of the disaster rehabilitation plan, using valid and reliable indicators.

Agir en réponse aux conséquences physiques et psychologiques des catastrophes naturelles : étude de cas du plan de relèvement post-catastrophe en Iran

RÉSUMÉ La présente étude décrit le processus d'élaboration d'un plan national de préparation aux catastrophes naturelles pour la santé physique et la réhabilitation psychologique des populations frappées par les catastrophes. Les données collectées à partir d'une analyse documentaire et de groupes de discussions d'experts ont permis la rédaction de définitions unifiées en matière de réhabilitation au plan de la santé physique et mentale, la conduite $d^{\prime}$ analyses des parties prenantes et d'analyses PEST(E)-V (politique, économique, sociologique, technologique et écologique, et questions liées aux valeurs), et l'attribution de chaque tâche à l'organisation responsable et aux organisations collaboratives. Le ministère de la Santé et l'Organisation de protection sociale ont été désignées comme les deux entités responsables. Une prise en charge intégrée à tous les niveaux, le partage de l'information, l'éducation et l'aide financière ont été identifiés comme les moyens de renforcer la participation et la collaboration des parties prenantes. L'établissement d'un système est requis pour évaluer la mise en œuvre du plan de relèvement post-catastrophe à l'appui d'indicateurs valables et fiables.

${ }^{'}$ School of Public Health, Tehran University of Medical Sciences, Tehran, Islamic Republic of Iran. ${ }^{2}$ National Institute of Health Research, Tehran University of Medical Sciences, Tehran, Islamic Republic of Iran. ${ }^{3}$ Harvard Humanitarian Initiative, Harvard University, Cambridge, Massachusetts, United States of America. ${ }^{4}$ School of Health, Safety and Environment, Shahid Beheshti University of Medical Sciences, Tehran, Islamic Republic of Iran. ${ }^{5}$ National Disaster Management Organization, Tehran, Islamic Republic of Iran (Correspondence to M. F. Latifi: faridlatifi4@gmail.com). ${ }^{6}$ Department of Mental Health, Ministry of Health, Tehran, Islamic Republic of Iran. ${ }^{7}$ Welfare Organization, Tehran, Islamic Republic of Iran. ${ }^{8}$ School of Health Management and Information Sciences, Iran University of Medical Sciences, Tehran, Islamic Republic of Iran.

Received: 27/05/15; accepted: 07/02/16 


\section{Introduction}

Natural disasters impose a great burden on populations, causing death, injury and psychological disorders and fracturing social as well as physical structures (1). Although the impact of disasters on humans is wide-ranging (2), physi$\mathrm{cal}$ and mental health problems of the affected population are the immediate concern after natural disasters $(3,4)$. Rehabilitation-the actions taken to provide support for the well-being of survivors in the aftermath of a disaster-focuses on enabling people to resumenormal patterns oflife (5). Clearly, the speed and success of rehabilitation is greatly enhanced when plans are in place prior to natural disasters to provide a framework for stakeholders to cope with the evolving conditions (6). Some studies have highlighted the necessity of planning for the restoration of people's health and a few have reported on rehabilitation planning for restoring the physical and mental health of damaged people (7-11). To our knowledge, however, no previously published paper has reported a pre-disaster rehabilitation plan.

The Islamic Republic of Iran is a highly disaster-prone country; during recent decades, disasters of different kinds have affected about 42 million Iranians and killed 78000 of them $(12,13)$. More attention is therefore needed to planning for physical and psychological health rehabilitation of affected people. Although some studies, carried out after the Bam earthquake in 2003, highlighted the mental and physical health problems and effective therapeutic interventions (14-16), no pre-disaster rehabilitation plans were in place. Furthermore, while there are a plethora of organizations to assist health agencies in the rehabilitation process, no national plans have been drawn up to manage the organizations involved after disasters and to avoid any duplication of efforts. To fill these gaps, the present paper reports on the process of developing a comprehensive pre-disaster plan for physical and psychological health rehabilitation in disaster-stricken communities in the Islamic Republic of Iran. The underlying purpose was to assist health practitioners and managers to deal with natural disasters by ensuring that their roles and responsibilities were clearly defined.

\section{Methods}

The rehabilitation plan was drawn up with the participation of 80 experts working in 34 governmental and nongovernmental organizations working in the field of disaster health management. The Iranian National Disaster Management Organization drew up the plan and supervised the project process. The project was handled by a research team who worked in the Department of Disaster and Emergency Health, at the National Institute of Health Research, Tehran. The research team carried out the literature review, data gathering and analysis and facilitated at expert panels, brainstorming and group discussions.

The phases of establishing the plan were as follows. First, a comprehensive literature review was made and expert discussions were carried out to finalize unified, acceptable definitions of physical health and psychological rehabilitation that would be applied by all involved organizations. Secondly, a stakeholder analysis and STEEP-V [social, technological, economic, environmental/ecological, political and value-based issues] analysis were made to establish the factors that will influence the Islamic Republic of Iran's post-disaster physical and mental health rehabilitation up to 2024. The third step was to ascertain the values, goals, objectives and strategies of the plan. Finally, the main responsible organizations and the relevant collaborative organizations as well as their responsibilities and collaborative functions were identified according to the data extracted from advisory and expert panels, with the participation of all involved organizations working in the field of disaster health management.

The stakeholder analysis was initiated by listing all related organizations that had a potential interest in and/or impact on post-disaster physical health and psychological rehabilitation. The list was drawn up by the research team via the advisory panels. This was followed by rating the organizations' levels of interest and of impact from 1 to 5 (positive to negative). This was carried out by representatives of the involved organizations at consensus meetings and expert panels, and the data were analysed by the research team. Higher scores represented higher levels of interest or impact.

The STEEP-V analysis was begun by brainstorming participants on factors that might have an influence on public policies, values, goals and strategies for physical health and psychological rehabilitation in either a favourable or unfavourable manner. At this stage, a subset of experts working in 34 governmental and non-governmental organizations participated through advisory and expert panels.

Expert panels, brainstorming and group discussions were the main methods of data gathering. Experts from relevant disciplines-disaster epidemiology, disaster and emergency medicine, rehabilitation management, and social welfare-were invited to join the panel discussions. In total, more than 20 advisory and expert panels were held with the contribution of 15-30 experts per session.

\section{Results}

\section{Physical health and psychological rehabilitation plan}

After the literature review and the stakeholders' consensus, the following definitions of physical health and 
psychological rehabilitation were approved:

- Physical rehabilitation: supportive interventions and services provided for people with physical disability caused by the disaster to help them cope with this special situation and act as productive individuals in their communities.

- Psychological rehabilitation: psychological supportive care and interventions provided after mental trauma resulting from disasters. Services would be provided for shocked and damaged people, providers and disaster managers in the short, medium and long term.

According to the stakeholder analysis, the following organizations and stakeholders had the highest interest in post-disaster physical health and psychological rehabilitation: the health workgroup of the National Disaster Management Organization (a governmental organization for managing disasters at the national and local levels); the relief, rescue and public education team of the National Disaster Management Organization; Ministry of Health; Iranian Red Crescent Society; University of Social Welfare and Rehabilitation Sciences; Iranian Blood Transfusion Organization; forprofit nongovernmental organizations; vulnerable groups and affected people; and community health workers (behvarzan). The stakeholders with the highest impact on physical health and psychological rehabilitation were identified as the Ministry of Health; Welfare Organization (a governmental organization responsible for providing a healthy life for poor and disabled people); World Health Organization; Basij Medical Association (a private association of medical experts); Passive Defence Organization (a private organization managed by the armed forces to provide the national security in pre- and post-disaster phases); and providers of health care, rehabilitation and social services (Table 1). Sharing

\begin{tabular}{|c|c|c|}
\hline Stakeholder/group & $\begin{array}{l}\text { Level of } \\
\text { interest }^{\mathrm{a}}\end{array}$ & $\begin{array}{l}\text { Level of } \\
\text { impact }^{\text {a }}\end{array}$ \\
\hline Ministry of Health & +5 & +5 \\
\hline Community health workers & +5 & +5 \\
\hline $\begin{array}{l}\text { National Disaster Management Organization- } \\
\text { health team }\end{array}$ & +5 & +3 \\
\hline $\begin{array}{l}\text { National Disaster Management Organization- } \\
\text { relief, rescue and public education team }\end{array}$ & +5 & +3 \\
\hline Iranian Red Crescent Society & +5 & +3 \\
\hline Iranian Blood Transfusion Organization & +5 & +3 \\
\hline $\begin{array}{l}\text { University of Social Welfare and Rehabilitation } \\
\text { Sciences }\end{array}$ & +5 & +2 \\
\hline Vulnerable groups and affected people & +5 & +1 \\
\hline For-profit nongovernmental organizations & +5 & +1 \\
\hline $\begin{array}{l}\text { Humanitarian associations supporting } \\
\text { rehabilitation services }\end{array}$ & +5 & +1 \\
\hline Welfare Organization & +4 & +5 \\
\hline $\begin{array}{l}\text { Providers of health care, rehabilitation and social } \\
\text { services }\end{array}$ & +4 & +5 \\
\hline World Health Organization & +4 & +5 \\
\hline Passive Defence Organization & +4 & +5 \\
\hline World Bank & +4 & +3 \\
\hline Social Work Association & +4 & +3 \\
\hline Non-profit organizations & +4 & +2 \\
\hline Consultant clinics & +4 & +2 \\
\hline Basij Medical Association & +3 & +5 \\
\hline Nursing Organization of Iran & +3 & +3 \\
\hline Psychological Organization of Iran & +3 & +2 \\
\hline United Nations Children's Fund & +3 & +2 \\
\hline Central bank and other banks & +3 & +2 \\
\hline Central Insurance Organization & +3 & +2 \\
\hline Iranian Medical Council & +2 & +3 \\
\hline
\end{tabular}

${ }^{a}$ Numbers show the strength of trends and signs show the trend direction.

information, education and funding were identified as the best methods of improving stakeholders' participation and collaboration.

The most important factors revealed by STEEP-V analysis are shown in Table 2. Such social, technical, economic, environmental, political and value-based issues will affect the whole operation of the physical health and psychological rehabilitation plan up to the year 2024; the STEEP-V factors will be reviewed and updated after 10 years. For example, the media's role in keeping people informed about the rehabilitation plan and services had the highest positive score in the technological category, while inadequate basic services with unqualified staffing had the greatest negative score. In addition, population vulnerability was identified as the strongest negative factor in the social group. Policy-making and planning for disaster rehabilitation, and training responsible human resources, had the highest positive ratings in the political and value-based category.

The policies of physical and psychologicalhealth rehabilitationwere defined as follows: integrated rehabilitation 
management at all levels; knowledge management based on scientific evidence and local technology; use of religious associations and institutions for facilitating rehabilitation efforts; a focus on vulnerable groups such as children and elderly and disabled people; community-based rehabilitation planning; and comprehensive physical health and psychological rehabilitation in line with sustainable development. The values which should be followed by all responsible and collaborative organizations were described as: to consider human dignity; to focus on equality in all the stages; to act in line with national values and autonomy; and to take into account the concepts and values of Islam.

\section{Goals, strategies and responsible and collaborative organizations}

The goals and strategies of physical health and psychological rehabilitation and the responsible and collaborative organizations were identified in accordance with the policies and values defined above, as well as the stakeholder analysis and STEEP-V outputs.

\section{Physical health rehabilitation}

Goal: rapid and effective restoration of physical capabilities of people disabled by disasters, as well as those with preexisting disabilities, to allow them to perform routine activities of life independently.

Strategies: standardization of physical rehabilitation services; development of technical, financial and human resources to provide the necessary services; and establishment of networks for physical rehabilitation services. Health.

Responsible organization: Ministry of

\section{Collaborative organizations: Welfare} Organization, Iranian Red Crescent Society, Social Security Organization and Basij Medical Association.

\section{Psychological health rehabilitation}

Goal: to prevent and treat psychological disorders resulting from natural disasters
Table 2 STEEP-V analysis of the social, technological, environmental, economic, political and value-based factors that will impact on the Islamic Republic of Iran's post-disaster physical health and psychological rehabilitation up to 2024

Factors $\quad \begin{gathered}\text { Strength and trend } \\ \text { direction }^{\mathrm{a}}\end{gathered}$

\section{Social factors}

Public demands for rehabilitation services $\quad+2$

Public knowledge about available services $\quad+1$

Numbers of affected people $\quad+1$

Drug dependency -2

Negative attitudes of people to the quality of

rehabilitation services

Lack of community partnership $\quad-4$

Lack of social capital $\quad-4$

Vulnerability of the population $\quad-5$

Political and value-based factors

Rehabilitation policies and plans $\quad+5$

Training responsible human resources $\quad+5$

Religious associations and institutions for facilitating

rehabilitation efforts +5

Reinforcement and improvement of mental health plans $\quad+3$

Lack of focus on equality, human dignity and quality of life $\quad-2$

Lack of punctuality and flexibility in providing

rehabilitation services

Lack of a teamwork culture and multi-disciplinary collaboration

Foreign threats and sanctions

Lack of coordination and management

\section{Technological factors}

Media role in keeping people informed about the rehabilitation plan and services

Availability of information technology +3

Capacity of rehabilitation services +3

Knowledge management $\quad+2$

Public health indicators $\quad+2$

Research and educational technology $\quad+2$

Man-made hazards $\quad-3$

Inadequate basic services and unqualified staffing $\quad-3$

\section{Environmental and economic factors}

Resource allocation related to rehabilitation $\quad+1$

Islamic Republic of Iran's natural hazard profile $\quad-2$

Disaster vulnerability in the involved organizations $\quad-2$

Inadequate social/disaster insurance and financial institutions

Low economic status of the population

Lack of investments and participation of private sectors for providing rehabilitation services

Lack of financial savings to cope with disasters $\quad-5$

Social vulnerability and unequal development $\quad-5$

${ }^{a}$ Numbers show the strength of trends and signs show the trend direction. 


\begin{tabular}{|c|c|c|}
\hline Domain/organization & Pre-disaster tasks & Post-disaster tasks \\
\hline \multicolumn{3}{|c|}{ Physical health rehabilitation } \\
\hline \multirow[t]{6}{*}{$\begin{array}{l}\text { Responsible organization: } \\
\text { Ministry of Health }\end{array}$} & $\begin{array}{l}\text { Developing preparedness action plan } \\
\text { for post-disaster physical rehabilitation, } \\
\text { including preparing a pre-disaster list of } \\
\text { people with different kinds of disabilities }\end{array}$ & $\begin{array}{l}\text { Developing a comprehensive database } \\
\text { of post-disaster disabled victims and the } \\
\text { resources required for meeting their needs }\end{array}$ \\
\hline & $\begin{array}{l}\text { Carrying out needs and capacity } \\
\text { assessments of Ministry of Health } \\
\text { services and staff involved in providing } \\
\text { post-disaster physical rehabilitation } \\
\text { services }\end{array}$ & $\begin{array}{l}\text { Providing different kinds of physical } \\
\text { rehabilitation services for disaster-affected } \\
\text { people }\end{array}$ \\
\hline & $\begin{array}{l}\text { Capacity-building of physical } \\
\text { rehabilitation specialists (educating and } \\
\text { training) }\end{array}$ & $\begin{array}{l}\text { Delivering community-based services, } \\
\text { with a focus on developing the capacities } \\
\text { of affected populations }\end{array}$ \\
\hline & $\begin{array}{l}\text { Continuous planning for long-term } \\
\text { physical rehabilitation in disaster- } \\
\text { damaged health centres }\end{array}$ & $\begin{array}{l}\text { Continuing delivery of physical } \\
\text { rehabilitation services to disabled } \\
\text { individuals after disasters (supporting and } \\
\text { training) }\end{array}$ \\
\hline & $\begin{array}{l}\text { Planning for supplying facilities as well } \\
\text { as developing infrastructure for post- } \\
\text { disaster physical health rehabilitation }\end{array}$ & $\begin{array}{l}\text { Participating in management of } \\
\text { humanitarian aid related to physical } \\
\text { rehabilitation }\end{array}$ \\
\hline & $\begin{array}{l}\text { Capacity-building of specialized } \\
\text { nongovernmental organizations for } \\
\text { delivering physical rehabilitation services } \\
\text { after disasters }\end{array}$ & $\begin{array}{l}\text { Monitoring and evaluating physical } \\
\text { rehabilitation services }\end{array}$ \\
\hline \multicolumn{3}{|l|}{ Psychological rehabilitation } \\
\hline \multirow[t]{6}{*}{$\begin{array}{l}\text { Responsible organization: } \\
\text { Welfare Organization }\end{array}$} & $\begin{array}{l}\text { Developing preparedness action } \\
\text { plan for post-disaster psychological } \\
\text { rehabilitation, including preparing a pre- } \\
\text { disaster list of people with mental health } \\
\text { disorders }\end{array}$ & $\begin{array}{l}\text { Providing various types of psychological } \\
\text { rehabilitation services for disaster-affected } \\
\text { people, including developing a database } \\
\text { for recording cases of post-disaster mental } \\
\text { health disorders }\end{array}$ \\
\hline & $\begin{array}{l}\text { Developing guidelines and standards for } \\
\text { psychological rehabilitation services }\end{array}$ & $\begin{array}{l}\text { Continuing revision of the action plan } \\
\text { based on available resources and the } \\
\text { changing status of damaged areas }\end{array}$ \\
\hline & $\begin{array}{l}\text { Participating in the capacity } \\
\text { development of professional } \\
\text { nongovernmental organizations }\end{array}$ & $\begin{array}{l}\text { Identifying substance abusers and } \\
\text { providing mental health services for them }\end{array}$ \\
\hline & $\begin{array}{l}\text { Supporting research required for } \\
\text { improvement of psychological } \\
\text { rehabilitation }\end{array}$ & $\begin{array}{l}\text { Providing mental health services for rescue } \\
\text { and relief workers, disaster managers and } \\
\text { other aid providers }\end{array}$ \\
\hline & $\begin{array}{l}\text { Informing the community about the } \\
\text { psychological consequences of disasters } \\
\text { and the related rehabilitation services }\end{array}$ & $\begin{array}{l}\text { Providing virtual mental health services by } \\
\text { means of } 24 \text {-hour phone lines and online } \\
\text { web pages }\end{array}$ \\
\hline & $\begin{array}{l}\text { Providing regular, evidence-based } \\
\text { training for psychologists and social } \\
\text { workers }\end{array}$ & $\begin{array}{l}\text { Monitoring and evaluating psychological } \\
\text { rehabilitation services }\end{array}$ \\
\hline
\end{tabular}

in order to restore the mental health of people adversely affected by disasters.

Strategies: to establish psychological rehabilitation services; to develop and organize public/professional human resources; to provide standard psychological services based on gender and other social factors; to integrate mental health interventions into relief efforts; and to encourage positive thinking among the affected communities.

Responsible organization: Welfare Organization (an important public organization with the mission of supporting disabled and poor people in the Islamic Republic of Iran).

Collaborative organizations: Ministry of Health, Iranian Red Crescent Society, Social Security Organization, Psychological Organization and Basij Medical Association. 
The final part of the report summarized the most important tasks of the responsible organizations (Table 3).

\section{Discussion}

The present project represents the first attempt to develop a pre-disaster physical health and psychological rehabilitation plan for the Islamic Republic of Iran. Some studies have reported rehabilitation plans developed after a disaster $(12,13)$. Although these post-disasters plans may be successful, planning for physical and mental health rehabilitation is more effective if it is done before the occurrence of a disaster (6). A number of studies have highlighted the necessity of developing a pre-disaster rehabilitation plan for the physical and mental health of affected people (7-11). However, such a plan should be in line with the sociocultural context of the affected communities and the structure of the available disaster health management organizations.

The national rehabilitation plan for the Islamic Republic of Iran included providing unified terminology and definitions for physical health and psychological rehabilitation in order to avoiding misunderstandings during the rehabilitation phase. Based on the stakeholder and STEEP-V analyses, community health workers (behvarzan) had the highest score in both interest and impact on rehabilitation initiatives. It seems that the capacity of publichealth centres is important for effective implementation of the physical health and psychological rehabilitation plan. However, such capacity has not so far been applied for post-disaster physical health and psychological rehabilitation efforts in the Islamic Republic of Iran.

Pre-defined tasks of the responsible organizations and collaborative organizations can help them to work in a more coordinated way. These responsibilities were determined and approved by all the involved organizations in order to avoid any duplication of efforts after disasters. Social protection and financial support for vulnerable people, including children and disabled and elderly persons were also considered in the public policy.
It is recommended that a system be developed for evaluating the implementation of the physical health and psychological rehabilitation plan, using valid and reliable indicators. Additionally, the findings suggest that an executive guarantee, for example from the Office of the President of the Islamic Republic of Iran, should be made to enforce the involved organizations to fulfil their responsibilities before and after disasters. The plan was focused on natural disasters and further research will be required to make a comprehensive response and rehabilitation plan for man-made and bioterrorism emergencies.

\section{Acknowledgements}

The project was conducted by Department of Disaster and Emergency Health, National Institute of Health Research in Tehran. The authors gratefully acknowledge the participation of all involved organizations and stakeholders during planning process.

Funding: The plan was financially supported by the National Disaster Management Organization.

Competing interests: None declared.

\section{References}

1. Beaudoin CE. News, social capital and health in the context of Katrina. J Health Care Poor Underserved. 2007 May;18(2):41830. PMID:17483569

2. Guidance note on recovery: health. Geneva: United Nations Development Programme/International Recovery Platform/ United Nations Office for Disaster Risk Reduction; 2010 (http://www.unisdr.org/files/18782_irphealth.pdf, accessed 28 February 2016).

3. Rauch A, Baumberger M, Moise F-G, von Elm E, Reinhardt JD. Rehabilitation needs assessment in persons with spinal cord injury following the 2010 earthquake in Haiti: a pilot study using an ICF-based tool. J Rehabil Med. 2011 Nov;43(11):969-75. PMID:22031341

4. Ciottone GR, editor. Disaster medicine. 3rd ed. Philadelphia: Mosby Elsevier; 2006.

5. Aysan Y, Davis I. Rehabilitation and reconstruction. Geneva: United Nations Development Programme/Department of Humanitarian Affairs Disaster Management Training Programme; 1993.

6. National disaster recovery framework: strengthening disaster recovery for the nation. Washington (DC): Federal Emergency Management Agency; 2011 (http://www.recoveryplatform.
org/assets/tools_guidelines/predisaster_planning/US\%20 National\%20Disaster\%20Recovery\%20Frameworkv2.pdf, accessed 26 February 2016).

7. Gosney J, Reinhardt JD, Haig AJ, Li J. Developing postdisaster physical rehabilitation: role of the World Health Organization Liaison Sub-Committee on Rehabilitation Disaster Relief of the International Society of Physical and Rehabilitation Medicine. J Rehabil Med. 2011 Nov;43(11):965-8. PMID:22031340

8. Heimann P, Issakov A. Repair and recovery of health systems: WHO tools for evidence-based resource planning within the context of post-tsunami rehabilitation of health facilities and restoration of health services Geneva: World Health Organization; 2005.

9. Chowdhury M. Research report on a comparative study of disaster risk reduction and post disaster livelihood recovery program in Japan and Bangladesh. Kobe, Japan: Asian Disaster Reduction Center; 2012.

10. Pakistan floods 2010. Early recovery plan for the health sector. Islamabad: World Health Organization Health Cluster-Pakistan; 2011 (http://www.who.int/hac/crises/pak/ pakistan_early_recovery_plan_12february2011.pdf, accessed 28 February 2016). 
11. Post-disaster rehabilitation activities in India [Internet]. New Delhi, India: Aga Khan Development Network; 2001 (http:// www.akdn.org/india_rehabilitation.asp, accessed 28 February 2016).

12. Islamic Republic of Iran: disaster and risk profile. Basic country statistics and indicators [Internet]. Geneva: United Nations International Strategy for Disaster Reduction; 2011 (http://www. preventionweb.net/english/countries/statistics/?cid=81, accessed 28 February 2016).

13. Moaierinezhad $\mathrm{H}$. [The most destructive earthquakes of Iran] Tehran: Khabar Online; 2012 (http://www.khabaronline.ir/ detail/235750/society/urban, accessed 28 February 2016).
14. Farhoudian A, Sharifi V, Rahimi A, Radgudarzi R, Mohammadi $M$, Yunesian M. The study of PTSD prevalence and its symptoms in affected people of Bam earthquake. Journal of Cognitive Sciences News. 2006;8(3):58-70.

15. Ghomashchi F. The effect of problem solving education on treatment of PTSD patients of Bam earthquake. Journal of Ardebil University of Medical Sciences. 2008;8(3):294-300.

16. Rahimi A, Farhoudian A, Radgudarzi R, Sharifi V, Yunesian M, Mohammadi $M$. Revalence and change of drug use in affected people of Bam earthquake. Payesh Journal. 2006;6(3):209-17. 